This item was submitted to Loughborough's Research Repository by the author.

Items in Figshare are protected by copyright, with all rights reserved, unless otherwise indicated.

\title{
What do people think employee share ownership schemes do for them? A qualitative study of participants' experiences in three UK share schemes
}

\section{PLEASE CITE THE PUBLISHED VERSION}

https://doi.org/10.1080/09585192.2018.1445655

\section{PUBLISHER}

(c) Taylor and Francis

\section{VERSION}

AM (Accepted Manuscript)

\section{PUBLISHER STATEMENT}

This is an Accepted Manuscript of an article published by Taylor \& Francis in International Journal of Human Resource Management on 5 March 2018, available online:

http://www.tandfonline.com/10.1080/09585192.2018.1445655.

\section{LICENCE}

CC BY-NC-ND 4.0

\section{REPOSITORY RECORD}

McConville, David, John Arnold, and Alison Smith. 2019. "What Do People Think Employee Share Ownership Schemes Do for Them? A Qualitative Study of Participants' Experiences in Three UK Share Schemes”. figshare. https://hdl.handle.net/2134/32562. 


\title{
What do people think employee share ownership schemes do for them?
}

A qualitative study of participants' experiences in three UK share schemes.

\author{
David McConville, John Arnold, and Alison Smith
}

\section{Manuscript accepted for publication in International Journal of Human Resource Management}

\begin{abstract}
Research has produced mixed findings about the impact of participation in employee share ownership (ESO) schemes on employee attitudes and behaviours. Analyses of how participants themselves interpret ESO's effects could contribute to both theory-building and empirical evidence, but have not, to date, been undertaken. We conducted semi-structured interviews with 37 participants in three tax-advantaged ESO schemes in nine companies within the United Kingdom. Employees tended to feel that ESO had not increased their motivation, commitment or performance because they were already exhibiting these at a high level, as any good employee should. Even where this occurred, there was little evidence that employees thought ESO had strong effects, with the exception of staying with the company long enough to get a financial payoff. For some, this payoff was far from certain to materialise. There was some evidence that ESO was perceived to lead to a greater general sense of inclusion and that feeling special (e.g. being selected to participate) enhanced the perceived effects of ESO. We highlight the important roles of expectancy and instrumentality (expectancy theory) and conclude that the employee
\end{abstract}


experience of ESO reflects theory in some respects, but also offers new elements that theory may need to incorporate.

Keywords: Employee share ownership; motivation; commitment; expectancy theory 


\section{Introduction}

Employee share ownership (ESO) is a form of employee financial participation designed to encourage employees to acquire shares in the company in which they work (Pendleton, 2010), and to give them the right to share in the wealth of that company (Landau et al., 2007). ESO's capacity to influence employee attitudes and behaviours, and in turn affect individual and firm performance, has been a key reason why policy-makers support ESO (see Kaarsemaker, Pendleton and Poutsma, 2009). Some ESO studies, especially early ones, have investigated effects following an employee buyout, where the firm is completely employee-owned. In contrast, many others focus on firms where ESO provides employees with relatively fewer shares as part of a benefits package and the total percentage of the company owned by employees is significantly smaller (Kaarsemaker, Pendleton and Poutsma, 2009). Expectations and experiences of what it means to be an employee owner may differ significantly between these cases. This study focuses on three different HMRC (Her Majesty's Revenue and Customs) approved (tax-advantaged) share schemes in the UK. This includes two all-employee schemes (where all-employees and directors must be invited to participate), the SAYE (Save as you Earn, also known as ShareSave) and SIP (Share Incentive plan). The third, EMI (Enterprise Management Incentives) is a discretionary scheme. In this scheme, companies can choose which employees they would like to participate. Each is briefly described in Appendix $1^{1}$.

Overall, research has shown that simply participating in ESO or giving employees ownership in the company does not automatically change employees' attitudes or behaviours (Authors, 2016; Kruse 2002; Landau et al., 2007; McCarthy, Reeves and Turner, 2010; Pendleton, 2001; Sengupta, Whitfield and McNabb, 2007). In relation to employee commitment, a number of positive findings (e.g. Long, 1978a; Pendleton, Wilson and Wright, 1998; Tucker, Nock and Toscano, 1989) contrast with those suggesting little or no impact (e.g. French and Rosenstein, 1984; Kruse, 1984; Long, 1982). For employee satisfaction, some studies suggest ESO can 
improve employees’ job satisfaction (Long, 1978a; Long, 1978b; Long, 1982; Buchko, 1992) and some do not (e.g. Hammer, Stern and Gurdon, 1982; Keef, 1998). With regards to ESO and motivation, Freeman (2007) observes that studies tend to find (slightly) higher levels of motivation in employee-owned firms. Overall, the ESO research literature reports neutral to positive findings when exploring ESO's attitudinal effects. The same is true of studies of ESO's effects on individual and firm performance (Bryson and Freeman, 2010; Guedri and Hollandts, 2008; Kruse 2002). Furthermore, where effects on attitudes or behaviour are reported, they can rarely be described as major (Kaarsemaker, Pendleton and Poutsma, 2010; Knyght et al., 2010; Landau et al., 2007; McCarthy, Reeves and Turner, 2010; Pendleton, 2001; Sengupta, Whitfield and McNabb, 2007).

In earlier work, using the same dataset, we (Authors, 2016) explored the role of psychological ownership (PO) in some depth. The aim was to develop understanding of how employees interpret and make sense of the relationship between PO and ESO schemes, and whether employees felt that ESO had led to changes in PO or the routes proposed to lead to PO (Pierce, Rubenfeld, and Morgan, 1991). The study examined the role (or not) of PO in ESO participants' explanations of any changes in their attitudes or behaviours. We found that PO played little or no part in employees' explanations of how the ESO scheme impacted upon their attitudes or behaviours. Having explored the (non) role of PO in some depth, in this paper we therefore use other data from the same people to offer a broad-ranging analysis of how employees perceived and explained the impact (or not) of ESO on their attitudes and behaviours, and how the effects can be explained.

Although people do not necessarily have conscious awareness of the causal processes that affect them (Nisbett and Wilson, 1977), this study aims to inductively explore which elements of theory are most salient to ESO participants. The findings make an important contribution to the research literature, raising questions about the significance of claims that ESO enhances positive 
attitudes at work. Our findings contrast with a number of studies, including Jones and Kato (1995), Blasi, Kruse and Markowitz (2010) and Sesil et al. (2002) where performance effects were found or inferred. This study contributes understanding of how ESO's impact on employee attitudes (including employee commitment, motivation and job satisfaction) and behaviours can be explained (when found), and why claims about the impact of ESO are unlikely to ring true to most ESO participants in UK tax-advantaged schemes. We find support for a small number of studies suggesting that it is important to take pre-existing attitudes and behaviours into account when introducing ESO schemes, and when evaluating the impact of ESO (Caramelli and Briole, 2007; Pendleton, 2010; Pierce et al. 1991). We note how respondents' accounts of ESO’s effects (and lack thereof) were often closely aligned with the assumptions and components of expectancy (VIE) theory (Vroom, 1964). In order for ESO to have an effect, our findings infer that ESO schemes can be used to communicate to employees how important and valued they are to the company, whilst giving a clear indication of how employees can make money from the scheme in a way that meets their expectations.

The following sections present a review of the research literature, the methodology, a discussion of themes found in the data, and conclusions. This is followed by limitations and suggestions for future research.

\section{Literature Review}

Caramelli (2011, p. 9) argues that there is a lack of consistency in how ESO has been defined, the use of independent and dependent variables, and that more theoretical development is needed regarding the links between variables. Caramelli's general point is well taken, but nevertheless a number of theoretical perspectives have been developed which attempt to explain what effects ESO can be expected to have, and in what circumstances. This is important because ESO takes a 
wide variety of forms and names (Kaarsemaker, Pendleton and Poutsma, 2010), and it would therefore be surprising if it had uniform effects.

In our previous work, we (Authors, 2016) reviewed the links between ESO and the routes to PO; the attitudinal and behavioural effects of PO; and the role PO may play in explaining ESO's effects. In the following review, we focus on ESO (rather than PO) and present evidence from several different fields of research. First, we present findings and theories from labour economics and industrial relations, including principal-agent and gift exchange theories. These perspectives tend to focus on employee behaviour and performance at the firm level. We then address studies of organizational behaviour and work psychology, where the focus moves more towards individual level examinations of employee attitudes, and concepts such as employee motivation and job satisfaction. In the following sections we present key themes from these different fields of study, and identify some of the likely explanations for ESO's attitudinal and behavioural effects.

\section{Industrial relations and labour economics}

\section{Alignment of interests}

In economic theories of ESO (e.g. Blasi, Conte and Kruse, 1996; Sesil et al., 2002), aligning the interests of principals (employers/ managers) and agents (employees) is suggested to be a benefit of ESO, which incentivises employees and managers to work towards common goals. Employees may perceive only a weak connection between individual effort and reward, if for example the organization is large or if organizational performance and share value are seen largely as a function of economic factors outside the organization’s control (Blasi, Conte and Kruse, 1996). Nevertheless, it has been shown that where links between individual effort and reward are plausible, employees do tend to be more productive (or at least work harder) and sometimes monitor the behaviour of co-workers to make sure they do too (Freeman, Kruse and Blasi, 2010). 
In some forms of employee ownership, the employee has a lot of personal money invested in the organization, and the risks can be high (Markowitz, Blasi and Kruse, 2010). Expectancy theory (Vroom, 1964) suggests that employees will make an assessment of whether their actions are likely to achieve identifiable outcomes. In line with expectancy and instrumentality theories of motivation (Vroom, 1964), as long as some connection is perceived between personal performance and personal financial outcomes, we might expect that the higher an employee's financial dependence on ESO the greater the behavioural effects are likely to be (Long, 1982). However, this proposition has obtained mixed support. In a review of the literature, Freeman (2007) observed that a strong link between size of stake and motivation has not been convincingly demonstrated.

Within the field of industrial relations, a number of studies have examined the impact of ESO on firm performance, again producing mixed results (Blasi et al., 1996; Ben-Ner and Jones, 1995; Robinson and Wilson, 2006). Guedri and Hollandts (2008) explored possible reasons for this inconsistency. The longitudinal data, collected from 230 French firms, revealed an inverted U-shaped relationship between employee ownership and accounting-based measures of performance. Up to a certain point, ESO's impact on performance was positive, after which, the marginal effect of ESO then became negative (Guedri and Hollandts, 2008). In their discussion of the findings, Guedri and Hollandts (2008) postulate that ESO’s impact on firm performance will rely on positive changes in employees' attitudes, including their motivation, job involvement and satisfaction. These attitudinal changes will have a direct effect on productivity, according to Guedri and Hollandts (2008). Richter and Schrader (2016) also test the impact of ESO on three alternative measures of firm performance in companies from the five largest European economies. They conclude that over time ESO levels exert few performance effects. The marginal effects of ESO are found to decline as ESO levels increase. These studies, as with a number of others (e.g. Blasi et al., 1996; Kruse, 1996), raise questions about how the low (and mixed) effects of ESO 
can be explained, and the psychological mechanisms underlying the behavioural impact. We explore this in the present study.

\section{Gift exchange theory}

Drawing on Akerlof (1982), some studies in the field of labour economics have discussed how ESO might be seen as a gift from the organization which encourages employees to give something back (gift exchange), typically in the form of harder work but also possibly longer tenure and a greater felt loyalty to the employing organization (Bryson and Freeman, 2014). In ESO schemes employees buy shares at discounted rates, and/or are given shares or share options. The 'gift', in the context of ESO, is likely to refer to the opportunity to participate and be a share-owner, the reduced or pre-determined discount that is offered, or the award of free or matching shares. There is some suggestion that the reciprocation is more pronounced for weaker-performing employees who may believe they are being given something more than they have earned, whereas top performing employees conclude that they deserve it (Baron, 2013). However, the impact of a 'gift' of shares may be substantial even amongst high performers if it is interpreted as signalling that they are especially deserving or valuable to the organization (Caramelli, 2011), for example, when the shares are offered only to selected employees. Here the impact of ESO may be based less on gift exchange and more on personal self-esteem or even self-aggrandisement. Our study will allow us to explore these possible interpretations and reactions of employees to ESO.

\section{Employee participation}

In addition to gift exchange theory, it has frequently been suggested that ESO works best when it is just one manifestation of a larger package of measures aimed at promoting employee involvement and voice (Dube and Freeman, 2010; Pendleton and Robinson, 2010). At one level, simply owning shares often allows a form of participation, namely voting at the organization's 
AGM. However, the shares owned by any individual are very unlikely to make a material difference to any such votes. Freeman (2007) argues that satisfaction and motivation derive from increased participation, as opposed to size of ownership stake, or ownership per se. This is consistent with long-standing streams of research in both industrial relations (Pendleton, 2001) and organizational psychology (Kelly and Clegg, 1982) which have shown how participation in decision-making often has positive effects, likely through a combination of feeling valued and having more autonomy and control at work than might otherwise be the case. A number of studies in organizational behaviour (e.g. Klein, 1987; Klein and Hall, 1988) have examined if, and how, ESO's participation and control rights affect the satisfaction, motivation and commitment of employees.

\section{Studies of organizational behaviour}

In the field of organizational behaviour, ESO has been studied extensively. Credited as 'a landmark study' (Kaarsemaker, Pendleton and Poutsma, 2010, p. 325), 'influential on both the subsequent US and the UK literature' (Landau et al., 2007, p. 11), Klein (1987) proposed three different models of ESO. First, Klein's intrinsic satisfaction model suggested that the simple fact of ownership increases employees' commitment to, and satisfaction with, the company. This model was not supported in Klein's (1987) own findings, which suggested that intervening variables may be needed. The subsequent inconsistencies noted above in the labour economics and industrial relations fields about the effects of ESO support that conclusion.

The remaining two models presented by Klein (1987) provide deeper explanations of the mechanisms underlying ESO’s inconsistent effects on the attitudes and behaviours of participants. Klein's instrumental model proposed that ESO increases employee influence in company decision making, which then impacts on employee commitment. Despite some early negative findings (e.g. French and Rosenstein, 1984), employee participation in decision-making and having an influence 
at work have remained popular explanations of ESO's impact (see Pendleton and Robinson, 2010). However, the suggestion that employee participation in decision making is needed in order for ESO to have a positive impact, is questionable. In the industrial relations literature, the inflection point of the inverted U-shaped relationship between ESO and firm performance found in Guedri and Hollandts' (2008) study was not dependent upon the level of employee representation on the board. In the field of organizational psychology, participation in decision making has been theorised to lead to a feeling of control and influence, and a sense of PO over the ‘controlled' object (Pierce, Rubenfeld and Morgan, 1991). In the case of ESO, it is proposed that additional control rights will provide employees with a stronger sense that this is 'my' or 'our' organization, and consequently think, feel and behave more positively (Pierce et al. 1991). However, there is little empirical evidence to support this. McCarthy and Palcic's (2012, p. 3710) study, based on the data sourced from annual reports of Eircom, Ireland's former national telecommunications operator, and [Authors'] (2016) qualitative UK study, both fail to find evidence that participants perceived any effect of ESO on their attitudes or behaviours via feelings of PO.

A small number of studies suggest that an important consideration to make when evaluating employees' reactions to ESO, is the expectations they have when participating in the scheme (Caramelli and Briole, 2007; Pendleton, 2010; Pierce et al. 1991). This is because it is thought that ownership is likely to increase the expectancy perceptions of employees (Long, 1978b). Few studies have examined the links between ESO and employee expectations, or the ways employees think about and value the outcomes of their ESO participation. Expectancy theory would suggest that employees' judgements about the effectiveness of the ESO scheme, satisfaction and other attitudinal and behavioural changes, will depend on the employees' expectations and perceptions of the ESO scheme (Pendleton, 2010). Pendleton (2010) notes that these perceptions and expectations can also influence employees' decisions to participate in the scheme. The 
findings of some studies suggest that ownership can lead to positive attitudinal and behavioural outcomes, depending on what is expected and whether the individual values the outcomes. For example, Barba-Sánchez and Atienza-Sahuquillo (2017) found that the valence of business ownership predicted a person's motivation to remain self-employed. In another study, using expectancy theory, Hsu, Shinnar and Powell (2014) reported that individuals were motivated to become business owners when they felt that their effort would result in the desired goals (e.g. independence, social status etc.). However, few studies have applied expectancy theory when exploring ESO’s psychological impact.

\section{Financial rewards}

Klein's third model, known as the extrinsic satisfaction model, depends on ESO being financially rewarding. Klein’s (1987) findings suggested that the size of the company contribution to ESO was significantly positively related to organizational commitment, and significantly negatively related to turnover intention. A number of studies have since found support for this model (e.g. Buchko, 1992; Dewe, Dunn and Richardson, 1988) but as we note below, the effects of ESO via extrinsic satisfaction may be limited. Klein's extrinsic satisfaction model has clear resonance with economic thinking about ESO, though the link between personal effort and rewards is not essential to it - the more financial reward an employee gets through ESO, by whatever means, the more satisfied he or she is.

Similar explanations have appeared elsewhere in the literature. The 'golden handcuffs' explanation refers to how employee investments in ESO lead them to stay in the organization until a return can be realised, which due to ESO scheme rules and/or economic conditions may take a considerable and possibly uncertain amount of time. In a UK study, Sengupta, Whitfield and McNabb (2007) found lower levels of affective commitment in workplaces with ESO, which is consistent with an undermining of intrinsic motivation. Instead, continuance commitment - 'the 
perceived costs associated with leaving the organization’ (Meyer and Allen, 2002, p. 21) - helped to explain ESO’s positive association with labour productivity and financial performance.

However, some studies have suggested that employees with an investment expectation (sometimes called financial orientation) to ESO are unlikely to become infused in the organization, thus limiting ESO's potential to change their attitudes and behaviours. For these employees, Pierce et al. (1991, p. 130) explain that they will expect the value of their ownership stake to rise, and will feel they have a right to profits. Some motivation theory (Deci and Ryan, 1980) proposes that the obvious presence of extrinsic rewards serves to undermine the effects of intrinsic rewards. In their analysis of data from 37 companies with ESO, Klein and Hall (1988, p. 637) argue that employees are more satisfied with ESO when the contribution made by the company to the scheme is large, and when more money is made. However, Klein and Hall's (1988) empirical work reveals that whilst financial rewards are important, other factors also affect the satisfaction of employees. Klein and Hall (1988, p. 630) found that the characteristics of the ESO scheme contributed to employees' satisfaction with the scheme. Characteristics included the presence of voting rights, management's employee ownership philosophy (measured using three items, including 'employee ownership is a central part of our management philosophy'), communications (measured by counting the number of communications strategies the company used to communicate information about the ESO scheme), company contributions to the scheme, and the age of the scheme (Klein and Hall, 1988, p. 632). In addition, employee status within the scheme, employee values, interactions between employee and scheme characteristics, and employees' general attitude toward the organization as a whole (organizational commitment) were also found to affect employee satisfaction (Klein and Hall, 1988, p. 630). It is possible that the various ESO related characteristics mentioned cause employees to feel satisfied with the ESO scheme. However, it is also possible that the ESO scheme attracts employees who are more likely to be satisfied with the characteristics of the ESO scheme. The scheme may not necessarily be 
effective at attracting employees who have lower levels of job satisfaction, or those with lower levels of motivation. Klein and Hall’s (1988) study provides little insight into how attractive these ESO characteristics are to non-participants, or ESO's capacity to improve attitudes. It is also unclear whether enhanced satisfaction with the ESO scheme relates to job satisfaction, other attitudes such as employees commitment, or performance behaviours.

\section{Shared understanding}

Finally, we find in our review of organizational behaviour literature that the shared understanding employees have with managers may make a difference. As with some of the other studies mentioned in the field of organizational behaviour / psychology, Rousseau and Shperling (2003) draw on theories presented by economists (discussed earlier in 'principals and agents') which suggest that the alignment of interests between employees and managers will lead to more productive work behaviour. Rousseau and Shperling (2003, p. 561) argue that this is dependent upon 'a shared understanding regarding the psychological contract'. Mutual understanding will, according to Rousseau and Shperling (2003), influence how employees interpret and satisfy the psychological contract they have with their manager. In contrast to economic literature which suggests that employees are likely to violate the terms of an agreement unless deterrents are in place (i.e. punishments), Rousseau and Shperling (2003, p. 561), observe that in organizational psychology, the assumption tends to be that employees will remain motivated and committed to psychological contract agreements (without a need for sanctions or deterrents) if they are well understood. They also argue that a lack of information, poor communication and a lack of understanding can lead to behaviour that economists may refer to as 'shirking'. To strengthen the 'alignment of interests' between ESO participants and managers, it is argued that opportunities to develop a shared understanding are therefore needed. 


\section{Summary}

The ESO literature has presented mixed findings about its attitudinal and behavioural effects, and these connections are still elusive and poorly understood. Nevertheless, the various theories and empirical work offer a number of suggestions about how and when ESO will have such effects. We do not make hypotheses or aim to test objective relationships between variables, but we can identify factors which appear likely to affect ESO’s impact as identified by employees’ lived experiences of being ESO participants. These include whether employees believe and expect that their own actions can influence how financially rewarding it is, whether it is perceived as a gift from the employer, whether it is available to everyone or only to a chosen few, how much the person has invested in ESO, what the financial returns are likely to be and how soon they can be obtained, and whether ESO is part of a wider range of participative measures, or at least perceived to signal a participative culture. These factors are likely to vary significantly between ESO schemes, organizations and individual employees (Kaarsemaker, Pendleton and Poutsma, 2010; Poutsma, Kalmi and Pendleton, 2006; Sengupta, Pendleton and Whitfield, 2010).

Although several of the explanations of ESO effects described above invoke employee beliefs and perceptions, very few ESO studies investigate these directly. The vast majority of ESO studies exploring employee attitudes and behaviours have relied on large scale surveys, often focusing heavily on early models of ESO’s impact (e.g. Klein, 1987). It has been recognised that qualitative research would provide deeper insights into the processes described and sometimes tested in previous research (Knyght et al., 2010; Sengupta, Pendleton and Whitfield, 2010). As yet, only a small number of ESO studies have taken non-positivist, or mixed method approaches. Of those that have, Jackson and Morgan (2011) used interviews to discuss with UK employees their reasons for participating (or not) in Sharesave schemes. They found that it was largely seen as a means of saving for those who already intended to stay with their organization. Maaløe (1998) applied qualitative techniques and a phenomenological emphasis in order to chart cultural and 
change-management processes in an organization that switched to employee ownership. More recently, using different parts of the dataset reported here, [Authors] (2016) examined participants' explanations of how they feel their sense of PO is affected by participating in a company ESO scheme, finding little evidence of any link.

There is therefore a lack of published qualitative evidence which could help develop understanding and uncover the nuances of how employees experience the effects of ESO. We examine how UK employees, in three different schemes and nine different companies, make sense of ESO. We phenomenologically explore how they feel ESO has affected (or not) their commitment, satisfaction, motivation, job tenure intentions and performance at work - effects most often proposed in socio-psychological explanations of ESO.

\section{Method}

\section{The ESO schemes}

In the UK there are currently four different HMRC (Her Majesty's Revenue and Customs) approved (tax-advantaged) share schemes. These are SAYE (Save as you Earn, also known as ShareSave), SIP (Share Incentive plan), CSOP (Company Share Option plan) and EMI (Enterprise Management Incentives). SAYE and SIP are all-employee schemes (where all-employees and directors must be invited to participate) whilst EMI and CSOP are discretionary schemes where companies can choose which employees they would like to participate. In this study we focus on SIP, EMI and SAYE, each of which is briefly described in Appendix 1.

\section{Sample and procedure}

The sampling approach taken in this study was 'non-probability', the purpose of which is to identify people who may have information about the process being studied, as opposed to seeking a random or representative sample (Hornby and Symon, 1994). Although our intention was not to 
claim the findings to be representative of a larger population, we wanted the design of the study to permit comparisons between what was felt to be important by employees in different environments. We therefore sought three companies using each ESO scheme. We tried also to ensure that within each scheme there was variety in company sector and size, and that within each company there was variety in employee characteristics such as length of service and income. As Table 1 shows, we were fairly successful in these aims, though all three SAYE companies were very large. Table 1 describes the study respondents and companies included in this study and in Authors (2016), in which we explore participants' explanations of how they feel their sense of PO is affected by participating in a company ESO scheme.

\section{INSERT TABLE 1 ABOUT HERE}

In order to attract interest in the study, ESO scheme administrators in the UK agreed to forward letters summarising the study to ESO managers in their client companies. We also publicised the study at relevant conferences. Consequently companies contacted us directly if they were interested in being involved. We then provided further information with regards to number of interviews, time commitment and the type of questions that would be asked. We also briefed the ESO manager about ethical and data protection standards that would govern the research.

The ESO managers of participating companies were provided with an information sheet and criteria which they could use to select four interviewees. They were asked, if possible, to seek variation in terms of seniority of the employee in the company, the amount of shares or options the employee owned in the plan, how long the employees had worked for the company and how long they had been participating in the ESO plan. 
Thirty-seven semi-structured interviews with ESO participants of the SIP, EMI and SAYE schemes took place in nine companies in various UK locations. Prior to each interview, participants were given an information sheet explaining the project and their rights as participants. They also signed a consent form. The interviews were conducted in a private room at the interviewee's workplace and ranged in length from twenty five minutes to over one hour. Permission was granted by all participants for interviews to be audio recorded. Interviews were also conducted with an ESO manager in each company. For the purposes of this paper, these are used only to provide contextual information. Insights into manager expectations and additional contextual information about each company ESO scheme is provided in Appendix 2.

Interviews were guided by a set of questions with follow up questions and probes to help ascertain details of how employees thought about ESO and how they explained their experiences. Interviews were semi-structured; flexibility was used when it helped to elicit employee perceptions about if, how, when and why participation in ESO had affected them. The interviews were structured in the following order, addressing a number of areas, including: the way employees felt about the company they work for, and their job; why they participated in the ESO scheme and their expectations; their experiences of and reactions to the features of ESO; the extent to which they felt the scheme met their expectations; perceived changes in their attitudes and behaviour as a result of ESO; and reflections on their attitudes towards the company and their job. Follow-up questions ensured that, if employees didn’t discuss them spontaneously, the potential effects of ESO on motivation, commitment, satisfaction, performance, and length of tenure were covered.

\section{Data analysis}

The analytical approach taken in this study most closely resembled a process of Thematic Analysis as described in Braun and Clarke (2006). This can be defined as a method for 'identifying, 
analysing and reporting patterns and themes considered important in relation to the overall research question' (Braun and Clarke, 2006, p. 79). Data coding is the process of organizing the material into chunks or segments of text before bringing meaning to it (Creswell, 2009, p. 186).

The first author generated a draft set of codes which were discussed by all three authors, and a slightly revised set was produced. The codes were developed following the identification of concepts and theories found in the literature (e.g. Klein's three models of ESO), during data analysis, and from discussions and reflections on the data with co-authors. The first set of codes provided a way of organizing extracts and breaking down the transcripts for further analysis whilst maintaining focus on the aims of this study. Analysis was a recursive process, with movement back and forth (coding, re-coding, sub-coding), constantly re-evaluating extracts. Segments of coded text were then considered in more detail, segment by segment. During this process, codes were edited, new codes added, and overarching themes slowly emerged. In doing this, we highlight as closely as possible how employees interpret their experiences and the effects they feel arose from ESO participation.

To enhance validity (Arksey, 1999) conceptual definitions were drawn from the literature and used both during discussions and analysis to help clarify and make sense of feelings interviewees described. These concerned, for example, affective commitment (Meyer and Allen, 1984), continuance commitment and normative commitment (Allen and Meyer, 1990), organizational commitment (Porter et al., 1974), intrinsic motivation (Dysvik and Kuvaas, 2008), extrinsic motivation (Minbaeva, 2008), job satisfaction (VandeWalle, Van Dyne and Kostova, 1995), performance (Kuvaas, 2006), in-role behaviour and extra-role behaviour (Mayhew et al., 2007). Following the analysis, and after narrative had been added explaining the extracts and the links between them, we were satisfied that employees' stories had been interpreted from the data and that their own accounts were reflected in the findings. 


\section{Findings}

In this section we begin by reporting data on how employees reported that ESO did or did not affect their attitudes and behaviour at work. We use a broad range of attitudes and behaviours that emerged in our data coding. In the discussion that follows we then examine participants' comments and explanations regarding how they interpret the way ESO does or does not affect them, and discuss themes that help to inform our understanding and future theory-building about ESO. As we proceed, we will highlight where we see connections with, and illuminations of, other existing theory and research.

\section{Perceived effects of ESO on work attitudes and behaviours}

Instances of reported impact were minimal for most possible outcomes on all three schemes. Furthermore, analysis of participants' interview responses showed that where an impact was reported, it was in most cases described as small or minor, especially regarding work attitudes. For example:

....if there is a change, it's pretty slight. I mean at the time [of joining the scheme] it was nice to feel part of something, rather than just an employee. So, you do feel a little bit more engaged. I can't really explain much further than that to be honest. (EMI participant, Company 6).

Very few respondents felt that participation in any of the ESO schemes had a discernible impact on their satisfaction, sense of belonging or other attitudes toward their organization. We also found that two employees from the 37 interviewed reported that ESO had some impact on their job performance. Within this rather sparse picture it is noticeable that EMI was the only 
scheme to have virtually any reported effect on feeling trusted, feeling valued, feeling a sense of responsibility and work performance. Even for EMI, no more than a quarter of respondents reported any such effects. Even where they did, the perceived effects were uncertain and/or modest:

I don't think that just because I am a participant my productivity has shot right up, I don't see that no. But, perhaps slightly. Not enough to say absolutely yes. (EMI Participant, Company 4).

This finding about performance contrasts with a number of studies, including Jones and Kato (1995), Blasi, Kruse and Markowitz (2010) and Sesil et al. (2002) where performance effects were found or inferred. Of course, we are asking people for their perceptions rather than testing for causal connections between variables. This might explain the difference. Other possible explanations include already high levels of performance (i.e. a ceiling effect), or weak connections between perceptions of individual effort and reward (the '1/N problem'; Ben-Ner and Jones, 1995). We will return to these themes shortly.

Motivation fared just a little better, but still fewer than one in six respondents felt that ESO had made a difference. Almost a quarter of respondents, spread across all three ESO schemes, reported that ESO had some effect on their organizational commitment. By this we mean affective commitment (i.e. a sense of personal loyalty and identification with the organization), though some people expressing this also showed elements of continuance commitment - that is, being committed to staying for extrinsic reasons, most notably of course to reap financial benefits of ESO. For example: 
I suppose it makes me marginally more committed because I have some investment there yes...I care about what happens to the company because if the company succeeds then I stand to not only you know progress my career and enjoy my job, but to make some extra money on the side. (SAYE participant, Company 9).

Easily the most common outcome of ESO reported by our respondents was time spent in the company. This refers to expected tenure in the future, but it was sometimes accompanied by reasons why the participant had stayed until now. It was nearly always attributed to financial return (note also that both the previous two quotes refer to money, even though they are about motivation and commitment respectively). Nearly half the interviewees indicated that their future tenure with the company would be longer and/or more certain because of their participation in ESO. Employees considered a range of factors, including the opportunity to save money, tax savings, whether the scheme would produce a financial return and the attractiveness of the ESO scheme terms (e.g. the SIP matching rate, free shares, period of time before being able to exercise share options).

...if I was to leave I would be giving up the (share) options. I think the fact that I am tied in to the share plan for five years makes me think that I hope I am going to be around for the five years. (SAYE Participant, Company 9).

I think because of the terms of the plan, for example if you stay five years or more you are exempt from tax and NI (National Insurance), and if you are contributing quite a large amount, you could have quite a significant output to pay in tax if you left early. That plays a part in whether I will leave the company. (SIP Participant, Company 2). 
I had seen colleagues of mine take out share save plans and make an absolute fortune, you know...so I thought I will stick with the shares for five years, and you know, I am bound to make some money. (SAYE Participant, Company 7).

So with the important exception of continuance commitment (i.e. in this case staying due to money already invested in ESO and the expected or hoped for financial returns in the future), these findings suggest that claims that ESO enhances positive attitudes at work are unlikely to ring true to most ESO participants in UK tax-advantaged schemes. This is consistent with arguments that ESO alone is unlikely to induce changes in work attitudes and performance (Pendleton, 2001), and with Sengupta, Whitfield and McNabb’s (2007) 'golden handcuffs' account.

\section{Themes}

\section{How do employees explain these findings?}

The semi-structured interview design and the inductive analysis of the interview data provided an opportunity for unexpected themes to emerge. The analysis revealed that during the process of 'sense making' (Cassell and Symon, 2011) employees examined and reflected upon their own ESO experiences, frequently making (direct and indirect) links to their expectations of ESO. In our interpretation and analysis of the data, we conclude that the majority of the explanations given to explain ESO's perceived effects (or lack of them) can be linked to employees' expectations of what could be achieved (expectancy); their assessment of whether their actions were likely to achieve identifiable outcomes (instrumentality); and the value they attributed to the potential and expected rewards of being an ESO participant (valence). In other words, after themes had been identified and discussed amongst authors, we found that they were closely aligned with the assumptions and components of expectancy (VIE) theory (Vroom, 1964). Our findings build on 
the work of Long (1978a) and the theoretical work of Pierce et al. (1991, p. 133) in which it is stated that 'expectancy theory provides one of several paradigms that can articulate a process through which employee ownership can produce a set of social-psychological and behavioural effects'. Caramelli and Briole’s (2007) theoretical work also provides similar assertions relating to the ways in which ESO could motivate employees to think and act differently at work. With regards to expectations, Caramelli and Briole (2007, p. 292) suggest that the effect of ESO on the employee will depend on the employee believing that their effort will lead to increases in their own, and the company's performance. With regards to instrumentality, it is suggested that the employee needs also to believe that the increase in company performance will affect the value of company shares. Finally, in terms of valence, the increase in share value and financial returns must be meaningful and important to the employee. In Figure 1 we display the key themes identified in the data and what our interviewees said about them, which we interpret using the three components of expectancy theory.

INSERT FIGURE 1 ABOUT HERE

\section{Participation in company decision-making and processes}

Despite ESO helping some respondents feel part of the company, there was no evidence that this linked to participation as a result of ESO. Some participants did not know whether or not they were entitled to vote at company AGMs, and few showed much concern about it. Interestingly (and contrary to conventional wisdom) this study offers support for the proposition put forward 
by French (1987, p. 427), that ESO participants will be more likely to expect a return on investment, rather than greater control or participation in decision making.

There are voting rights, I got a letter in April, but I didn’t read it and that was something about voting, that is really bad isn't it? I don’t know if I have them, it is not something that I am interested in. (SIP Participant, Company 3).

...my vote now, because the shares are very much diluted.....would not have any impact. I don’t intend to vote at AGMs going forward. (SAYE participant, Company 9).

This separation of ESO participation from workplace decision-making seemed to extend beyond voting at AGMs to more day to day interpersonal contexts. Some research (e.g. Bryson and Freeman, 2014; Caron, Ben Ayed and Vandenberghe, 2013) shows that supervisors and coworkers are where the participative action is, but there was no evidence in our data that participation at this level was attributed to ESO:

I have a very good manager who supports me and allows me to make my own decisions, so it [control at work] has not really changed I guess. (SIP participant, Company 2).

Even in company 4, where ESO participants were something of a 'chosen few', only one respondent thought that greater participation might be an outcome, and even then it was tentatively expressed: 
Perhaps subtly....my Directors, they probably know I have got shares so possibly their attitudes have changed, but yeah, it is nothing I can pinpoint, no. (EMI participant, Company 4).

According to Arnold and Randall et al. (2010, p. 320), in expectancy theory the instrumentality question isn't worth asking if a person believes they are incapable of achieving the action or goal (expectancy). Employees did not appear to expect any additional control or participation rights in decision making from ESO participation, and did not feel they had received this. Therefore, it makes sense that they would feel incapable of being able to use any additional control or influence to improve firm performance. In terms of 'instrumentality', there was no evidence that employees felt that having additional influence would allow them to impact share price or company performance. Also, a lack of impact from ESO was not attributed by employees to a lack of participation in decision-making.

\section{Pre-existing attitudes and behaviours}

One reason frequently given for a perceived lack of effect of ESO across a number of potential outcomes was that positive work attitudes and behaviours were already being exhibited. The tone and wording of responses suggested that this was not simply a dispassionate logical point. Instead, it was a positive statement about the respondent's own values and integrity:

If $£ 125$ worth of shares was required for me to have those things then I should not be in my job in the first place. (SIP participant, Company 2). 
I think the profile of people recruited here generally wants to do a good job.... Did any of us work less [before the ESO scheme] or were we any less committed to the business? No we weren’t. (EMI participant, Company 6).

I never think, I am going to work a bit harder at this because I am a shareholder or in the Sharesave plan. I just think I will work as hard as I can on this because that is who I am. (SAYE participant, Company 8).

These quotes are in contrast to some of the research literature, which suggests that ESO is associated with higher productivity (e.g. Bryson and Freeman, 2010), although it is acknowledged that causality is hard to demonstrate (Freeman, Blasi and Kruse, 2010). As noted earlier, our respondents may not have been aware of their psychological processes and thus may have reported inaccurately. Be that as it may, it seems that claims about the motivational and productivity effects of ESO are best kept at arms' length from employees, who might be indignant to hear that their bosses believe their hard work and commitment can be bought by a share scheme. In relation to the expectancy and instrumentality components of expectancy theory, the majority of employees did not indicate during interviews that they expected ESO participation could, or would, lead to improved work attitudes, individual performance or share price. This may help to explain the lack of motivational impact we found in employees’ explanations of their ESO experiences.

Richter and Schrader (2016) found an inconsistent relationship between ESO and the individual level performance measure, 'sales per employee', but found ESO had an impact on other capital market and value generation measures. In the present study, we find that employees felt ESO had little or no effect on their own work performance. It could be argued that ESO firms outperformed non-ESO firms (in Richter and Schrader, 2016) because better performing firms are more likely to offer ESO schemes to employees. By implication, employees in better performing 
firms who are offered the opportunity to participate in ESO are likely to be performing relatively better than their counterparts in firms performing less well. This may be particularly true for firms with EMI schemes, where individuals are selected and invited to participate based on past performance. In other words, better performing firms may be more likely to introduce ESO schemes, and employees who are already performing well are more likely to have the opportunity to participate. In our findings it is possible that employees had 'reached their peak', and therefore did not feel they could work any harder. Responses suggested that this had occurred prior to joining the scheme. This could explain why ESO firms in Richter and Schraders' (2016) study outperformed non-ESO firms, whilst individual level performance (sales per employee) was not enhanced drastically by ESO.

\section{Are the financial benefits of ESO worth staying for?}

Nearly half the respondents reported that ESO affected how long they planned to stay in the company. This was nearly always because of the expected or hoped-for financial payoff. For these employees there appeared to be some belief (or hope) that the share price could rise and a return could be made. However, there was little evidence overall that ESO participants felt they could influence the financial return they hoped to receive (instrumentality). The reasons why not everyone reported that they would stay employed longer in the company because of ESO, give further insights into the experience of ESO. These revolve around (i) ESO being insignificant and forgettable, and (ii) ESO not being expected to make any money.

Where ESO was regarded as insignificant and forgettable (e.g. “I just leave it, don’t think about it”), this was for one or both of two inter-connected reasons. First, the amount of money at stake was not seen as sufficient to affect work behaviour. Second, the plan was seen as too long term to think about. Examples of these opinions are: 
I think of it as a long term plan, so I don't think about it. What makes me remember it is when I receive the annual letter, I think, oh, I still have this plan. (EMI participant, Company 5).

I can see the benefits, but at the moment they seem so far off and so minimal, that, you know, like I say, the whole...it has been quite opaque right from the start and felt quite unclear. Nobody talks about it. (EMI participant, Company 6).

Employees' 'out of sight, out of mind' attitude to ESO is likely partly due to a perception that the longer the time interval, the more the danger that unexpected events will undermine the financial return on the plan. It also fits with utility models of value that discount benefits that are far in the future (Walther, 2010).

Where ESO was not expected to make money, respondents gave two reasons why this might be the case. First, stock market volatility meant that shares or options purchased a few years earlier were worth less than had been paid for them, and might continue to be so for quite some time in the future.

The share options, as I say, are worthless at this point in time, right now I should be more concentrated on maintaining or keeping my job. (SAYE participant, Company 9).

Second, participants did not see a connection between what they did and the share price (instrumentality). This meant that whilst they might get a financial return, they might not and there was nothing they could do about it. An employee in Company 3 (SIP) explained that he and his colleagues felt there was a 'disconnection' between the employees' efforts and the share price. Another respondent elaborated on this theme: 
.....I don't think there is any bearing on the share price of what I do. So I could do a spectacularly good job, and my Sharesave (SAYE) plans will still be worth nothing. So it really is luck. (SAYE participant, Company 7).

These two reasons (a lack of expectancy and instrumentality) may help to explain why there was no discernible relationship between the amount of shares or share options held (where this was known by the respondent) and the perceived effects of ESO. Where the amount invested was discussed, it was more common for employees to say it would make no difference to them than that it would. Also, where respondents did feel the amount of shares owned would make a difference, they tended to invoke the pre-existing attitudes and behaviours theme, as if they did not want to appear easily swayed by money:

No, it wouldn't change anything. When I bought the first lot and the share value dropped significantly, so they were almost, you know, worthless, it didn’t really affect the way I felt. I just really wanted the company to turn around. (SIP participant, Company 2).

...if I had large numbers (of shares)...then it would have a bigger effect, but I mean I am well motivated anyway, so I don’t feel that it has added to that. (SIP Participant, Company 1).

\section{Gifts and feeling 'special'}

We have already noted that Company 4 selected people to be offered the chance to participate in its EMI scheme. The earlier quotes indicate that this was unexpected, perceived as a rather personal gift, and an endorsement of the person's contribution to the company. Caramelli (2011) emphasized the importance of providing employees with a clear message regarding how 
management value employees, and Company 4's approach seemed to do this at least for the chosen few:

...it (the offer to participate in the EMI) was a sign of recognition of effort, from the Chief Exec, and the higher level management team, that here is a guy that we want to entice, that he does make a difference, yeah, we will try to motivate him to stay with the company and not go off and do something else. (EMI Participant, Company 4).

The SIP scheme also permits the giving of shares by the employer but because SIP has to be offered to all employees, the 'gift' is less personal and the message about being valued is less clear. Company 1 offered free shares and employees did not have to (in fact, could not) buy any. This was appreciated as a gift but employees reported feeling motivated by working for an environmentally friendly approach to business and this seemed to minimise the felt impact of SIP. It also provided more evidence of the role of pre-existing attitudes:

I just thought, yes, that [the SIP] is quite a nice thing to do, but I don't feel more loyal than I did, because I am anyway. Everyone that works here, works here because they share in the ethical values... (SIP Participant, Company 1).

Bryson and Freeman (2012, p. 7) argue that, if share plan participation is part of a gift exchange, plan members will reciprocate with additional effort. This additional effort however, is not predicted if participants are simply trying to make a financial return. We find little support for the 'gift-exchange' theory. Some participants, especially in companies 1 and 4, interpreted ESO as a gift or positive gesture, but they explained very little in terms of 'exchange'. It would be 
difficult to infer from employees’ descriptions in this study that being selected or given free shares led to any significant changes in individual or firm performance.

In the EMI scheme, the (unexpected) awards were based on past performance, for which recipients had already been recognised and rewarded. Their expectations had therefore already been met or exceeded. This may have reduced the motivational effect, especially as most employees did not see a clear link between their own individual performance and share price, and the plan was seen as 'long term'. However, the EMI was the only scheme to have virtually any reported effect on feeling trusted, feeling valued, feeling a sense of responsibility or work performance. Even for EMI, no more than a quarter of respondents reported any such effects. In the SIP, again, the matching and free shares were perceived more as a result of their work, rather than an incentive to work harder.

Despite the general lack of perceived effect of ESO on most work attitudes and performance, some respondents who perceived the offer to participate or the matching or free shares as a gift, and felt 'special', tended to draw a contrast between being 'just' an employee and being an ESO participant. This has already been illustrated in the first quote in the findings section. What exactly ESO participation turned a person into was less clear, but despite this, it does rather suggest that ESO was perceived to have some effect in how employees viewed themselves at work:

.....Quite often you do feel like a shareholder because.... (pause) you have a stake in the company, you have a voice, you're not just an employee. (SAYE participant, Company 7).

So yeah, because of being part of the scheme I do feel I am part of the company rather than just an employee. (EMI participant, Company 4). 
These quotes suggest that ESO feeds into, or possibly induces, a separation in people's minds between being an employee and being, in some sense, part of things. This seemed to be an intra-personal phenomenon, since none of the interviewees indicated that they viewed their nonESO colleagues as second class citizens. The fact that two participants from company 4's EMI scheme drew the contrast between employee and shareholder is perhaps because they were selected by senior management to receive the share options (see Appendix 2) and therefore may have had particular reason to feel 'part of things'.

\section{Discussion}

In this study we have presented a methodological contrast to previous studies (e.g. Pendleton, 2010), drawn on theories of the impact of ESO (such as Klein's instrumental, intrinsic satisfaction and extrinsic satisfaction models), and examined how employees perceive and explain the effects of ESO. We find the explanations and themes align with expectancy theory, particularly its expectancy and instrumentality components. In the majority of cases, participants did not feel they could influence the performance of the company or share price. Few employees felt that the ESO scheme could, or would, lead them to work harder. As discussed, it is possible that better performing firms are more likely to introduce ESO schemes, which (if correct) would suggest that relatively higher performing employees (who may also feel that cannot work any harder) are more likely to be offered opportunities to participate in ESO than employees in companies performing less well. This, and the lack of impact found on employee performance, assists in explaining why Richter and Schrader (2016) found that employee performance (sales per employee) was not enhanced drastically by ESO, yet ESO firms outperformed non-ESO firms.

We elicit from the data that most employees felt that until their shares or options needed to be checked (e.g. at the end of the savings period in the SAYE) they could be forgotten about. Employees felt they had little or no influence over the financial return. ESO participation was nice 
to have and the possibility of making a financial return encouraged about half the respondents to report that they would stay with their employer and wait for it. However, respondents indicated that ESO participation did not on the whole significantly change what they thought, felt, or did whilst at work. ESO was a good thing primarily because they might make money from it, though by no means everyone thought that they would. The possibility that their affective commitment, motivation or performance at work would be influenced by participation in an ESO scheme seemed implausible to most employees. Of Klein's (1987) three models, our findings therefore most closely reflect the extrinsic model that ownership leads to behavioural change because it is financially rewarding. However, this is only observable for intention to stay with the company.

In studies where an impact has been found on firm performance, this may be due in part to ESO’s 'golden handcuffs' (Sengupta, Whitfield and McNabb, 2007) influence on employees. ESO provides an increased incentive to stay, leading to knock-on effects which may produce greater efficiencies (e.g. lower hiring/firing costs) without employees feeling they themselves are working any harder or better because of ESO. Given the relatively high number of participants who reported an effect of ESO on the amount of time they would stay employed in the company, these potential efficiencies may have applied to the companies in this study.

ESO managers had mixed and on the whole rather unelaborated views of what ESO might achieve, but they usually included financial gain for employees and retaining them for the company, often (but not always) with additional propositions about motivation, satisfaction and reinforcing company culture (see Appendix 2). Our findings suggest that ESO managers, as well as politicians and corporate leaders, would be well advised to be circumspect about the benefits of ESO they highlight when trying to promote participation in the scheme. Since the 1980s, a key policy objective of UK governments has been to enhance, and widen the use of ESO (Pendleton, 2001). This study raises the question of whether participants in ESO believe that it achieves what it is claimed to achieve. 
This generally negative conclusion needs to be tempered a little, however. About a quarter of respondents thought their affective commitment had been affected by ESO, and a sixth reported the same for motivation. Also, even though most respondents who reported effects on their commitment and motivation thought these were small and/or uncertain, nobody said that their commitment, motivation or any other attitude had been reduced by ESO. Further, some respondents felt, in a diffuse way, more 'part of things' and somehow different from when they were a run of the mill employee. Experientially, then, and in contrast to some motivation theory (Deci and Ryan, 1980), the dominant extrinsic narrative around the benefits of ESO did not eliminate the more intrinsic outcomes, though we cannot rule out the possibility that it reduced them. This also suggests that previous ESO literature (e.g. Pierce et al., 1991; Bryson and Freeman, 2012) may have over-drawn the contrast between financial and intrinsic orientations.

Our participants’ responses offer some insights that can inform future theory and research. At least in the context of these three UK schemes, there is no evidence that ESO was seen as part of a set of participative company practices that involved employees in company decision-making. Proponents of participation explanations of ESO might therefore argue that it is not surprising that employees thought ESO had few effects (Freeman, Blasi and Kruse, 2010). On the other hand, there was also no evidence that our respondents expected ESO to be part of a bigger set of participation practices. Therefore accounts of ESO that major on participation may not be reflecting employees' lived experience of ESO, at least in the UK context.

We found little evidence that respondents construed ESO as a gift, except perhaps in Company 4 where they were selected for participation on the basis of their contribution to the company. It seems that feeling special is what mattered - a gift that was given to everyone was a company policy, not a present. More important, perhaps, participants were resistant to the idea that ESO, gift or not, could induce responses of more motivation, commitment and (particularly) performance. They frequently argued that they were already doing all they could in these respects, 
and not to do so would be unprofessional. Again, this suggests that caution is needed in the way ESO is sold to potential participants. From a research point of view, it emphasizes the value of taking pre-existing attitudes and behaviours into account when evaluating the impact of ESO. As we indicated earlier, we do not claim that employees' reports necessarily reflect causal processes (c.f. Illes, 2006). Also, our respondents could not be sure how they would be feeling and acting at present if they were not ESO participants, though some could and did compare with themselves at a time in the past when they were not ESO participants.

Finally, we return to the financial and tenure elements of ESO. Although half our respondents said that the ESO scheme would increase their tenure via its financial returns, half did not. This was for several reasons. Employees did not always anticipate that their participation in an ESO scheme would make money, and indeed some thought they could lose out if share prices did not recover. So this is not a sure-fire way of ensuring that employees intend to stay with the company. Also, respondents felt that the long-term nature of some of the schemes meant that the pay-off was too much in the background and too uncertain to influence their behaviour. Thus, although longer-term schemes may seem likely to maximise the retention effect of ESO, they may instead have the opposite effect. Employees perceived that they had little influence on company performance, and even less on company share price, so in their eyes they could not influence their financial return from ESO. Although we did not directly ask about it, no interviewee mentioned trying to influence the effort and performance of those around them, in contrast to the suggestion made by Freeman, Kruse and Blasi (2010). Given our other results, this means that if employees think there will be little or no financial benefit of participation in ESO, there are no obvious alternative positive outcomes that can compensate.

\section{Limitations}


The ESO schemes in this study were operating in a less than favourable environment, with falling share prices and in some cases the share price being lower than the value of the discounted share option. The uncertainty and risk may therefore have affected ESO's capacity to influence employees. Nevertheless, interviewees were asked to reflect on their experiences of ESO over the years employed in the company, and many had experiences of ESO well before the recession. It is also possible that some employees were selected by managers because the manager felt they were relatively motivated or hard working, and would provide a good example of ESO's positive impact. Managers may have believed ESO had caused these positive attitudes and behaviours, whereas, it may instead be that motivated and harder working employees are more likely to join the scheme. Nevertheless, the findings reiterate the importance of taking pre-existing attitudes and behaviours into account when offering ESO schemes to employees, and when evaluating ESO's impact.

Qualitative research is sometimes accused of relying too much on the researcher's views about what is significant and important (Bryman, 2004). The researchers are the main instrument of data collection and so what is heard and what the researchers decide to concentrate on is, to some extent, a product of their predilections and own interpretations. To help overcome this, employees were able (and often asked) to discuss, clarify, explain and elaborate, in order to help the interviewer as much as possible see the world through the interviewees' eyes. The researchers take the position in this study that the interviewees attempted to provide explanations which they felt, at that time, were important and in their minds 'true'.

\section{Conclusions and future research}

In summary, the findings suggest that paying specific attention to how ESO schemes can be used as a way of communicating to employees how important and valued they are to the company, whilst giving a clear indication of how employees can make money from the scheme in a way that 
meets their expectations, could help lead to a deeper understanding of ESO's positive attitudinal changes. Whether all-employee schemes and schemes with no free share element have any potential to achieve attitudinal change, particularly in cases where employees do not feel that the scheme will lead to financial gain, may also be a worthwhile area for future research. The EMI was the only scheme to have virtually any reported effect on feeling trusted, feeling valued, feeling a sense of responsibility and work performance. Like the EMI Scheme, Incentive Stock Option Plans in the US are also discretionary, and as with the SIP, shares can be donated to employees in the ESOP in the US. The discretionary and free share elements of these plans could be examined further to ascertain the transferability of our findings to similar schemes in different contexts and cultures. Further exploration, possibly in combination with a study of innovative methods companies are increasingly using (e.g. text messaging, games, audio CDs) to inform and alert employees to ESO, might help uncover more detail about how employees think about ESO. Finally, it may be of interest to policy makers and researchers to consider more closely whether the employees who stay longer because of ESO are those the organization would most like to retain, and the nature of any multiplier effects resulting from this.

\section{Acknowledgements}

The authors would like to acknowledge with thanks the financial support provided to the study by (names of sponsors have been concealed for review purposes). The authors would also like to thank the ESO Administrators who provided help in attracting companies to participate in the study. 


\section{References}

Allen, N. and J. Meyer (1990). 'The measurement and antecedents of affective, continuance, and normative commitment to the organization’. Journal of Occupational Psychology, 63, pp. 1-18.

Akerlof, G. (1982). Labour contracts as partial gift exchange. Quarterly Journal of Economics, 97, pp. 543-569.

Arnold, J. and Randall, R. et al. (2010) Work Psychology: Understanding Human Behaviour in the Workplace. Harlow: Pearson Education.

Arksey, H. (1999). Interviewing for Social Scientists. London: Sage.

Authors (2016). Reference withheld to preserve author anonymity, but disclosable at the editor's discretion.

Barba-Sánchez, V, and Atienza-Sahuquillo, C. (2017). Entrepreneurial motivation and selfemployment: evidence from expectancy theory. International Entrepreneurship and Management Journal. 1-19.

Baron, J. N. (2013). Empathy wages?: Gratitude and gift exchange in employment relationships. Research in Organizational Behavior, 33, pp. 113-134.

Ben-Ner, A. and D. Jones (1995). 'Employee participation, ownership, and productivity: a theoretical framework’. Industrial Relations: A Journal of Economy and Society, 34, pp. $532-53$

Blasi, J., M. Conte and D. Kruse (1996). 'Employee stock ownership and corporate performance among public companies’. Industrial and Labor Relations Review, 50, pp. 6079.

Blasi, J. R., Kruse, D. L. and H. M. Markowitz (2010). Risk and lack of diversification 
under employee ownership and shared capitalism. In: Shared Capitalism at Work: Employee Ownership, Profit and Gain Sharing, and Broad-based Stock Options (pp. 105-136). University of Chicago Press.

Braun, V. and V. Clarke (2006). 'Using thematic analysis in psychology’. Qualitative Research in Psychology, 3, pp. 77-101.

Bryman, A. (2004). Social Research Methods. Oxford: Oxford University Press.

Bryson, A. and R. Freeman (2010). How does shared capitalism affect economic performance in the United Kingdom?. In: Shared capitalism at work: Employee ownership, profit and gain sharing, and broad-based stock options (pp. 201-224). University of Chicago Press.

Bryson, A. and R. Freeman (2012). 'Company share plans-gift or incentive? Evidence from a multinational corporation'. LSE Centre for Economic Performance, London, UK. Available at: http://cep.lse.ac.uk/conference_papers/26_05_2011/bryson.pdf.

Bryson, A. and R. Freeman (2014). Employee Stock Purchase Plans: Gift or Incentive? Evidence from a Multinational Corporation. IZA Discussion Paper, No. 8537. Available at: http://ftp.iza.org/dp8537.pdf

Buchko, A. (1992). 'Effects of employee ownership on employee attitudes: a test of three theoretical perspectives'. Work and Occupations, 19, pp. 59-78.

Caramelli, M., \& Briole, A. (2007). Employee stock ownership and job attitudes: Does culture matter?. Human Resource Management Review, 17, 290-304.

Caramelli, M. (2011). 'Towards a theory of the attitudinal effects of employee stock ownership’. INSEEC Business School, Paris, France. Available at: http://smlr.rutgers.edu/smlr/sites/smlr/files/Towads\%20a\%20Theory\%20of\%20Attitudinal\%2 0Effects\%20of\%20Employee\%20Stock\%20Ownership_Manuscript\%20Marco\%20Caramelli _La\%20Jolla.pdf. 
Caron, I., Ben-Ayed, A. K. and C. Vandenberghe (2013). Collective Incentive Plans, Organizational Justice and Commitment. Relations Industrielles/Industrial Relations, 68, pp. 95-119.

Cassell, C., \& Symon, G. (2011). Assessing 'good' qualitative research in the work psychology field: A narrative analysis. Journal of Occupational and Organizational Psychology, 84, 633-650.

Creswell, J. (2009). Qualitative Inquiry and Research Design. London: SAGE.

Deci, E. L. and R. M. Ryan (1980). The empirical exploration of intrinsic motivational processes. Advances in experimental social psychology, 13, pp. 39-80.

Dewe, P., S. Dunn and R. Richardson (1988). 'Employee share option schemes, why workers are attracted to them’. British Journal of Industrial Relations, 26, pp. 1-20.

Dube, A. and R. B. Freeman (2010). Complementarity of shared compensation and decision-making systems: evidence from the American labor market. In: Shared Capitalism at Work: Employee Ownership, Profit and Gain Sharing, and Broad-based Stock Options (pp. 167-199). University of Chicago Press.

Dysvik, A. and B. Kuvaas (2008). 'The relationship between perceived training opportunities, work motivation and employee outcomes'. International Journal of Training and Development, 12, pp. 138-157.

Ellingson, J. E., \& McFarland, L. A. (2011). Understanding faking behavior through the lens of motivation: An application of VIE theory. Human Performance, 24, 322-337.

Freeman, S. (2007). 'Effects of ESOP adoption and employee ownership: 30 years of research and experience', (Working Paper No. 07-01) University of Pennsylvania, Philadelphia, PA. Available at: www.aeoa.org.au/docs/0024/ESOPs\%2030\%20years\%20of\%20research.pdf

Freeman, R., Kruse, D. and J. Blasi (2010). Worker responses to shirking under shared 
capitalism. In: Shared capitalism at work: Employee ownership, profit and gain sharing, and broad-based stock options (pp. 77 - 103). University of Chicago Press.

Freeman, R., Blasi, J and D. Kruse, D (2010). Introduction to "Shared Capitalism at Work: Employee Ownership, Profit and Gain Sharing, and Broad-based Stock Options". In: Shared capitalism at work: Employee ownership, profit and gain sharing, and broad-based stock options (pp. 1 - 37). University of Chicago Press.

French, J. (1987). ‘Employee perspectives on stock ownership: financial investment or mechanism of control?’. Academy of Management Review, 12, pp. 427-435.

French, J. and J. Rosenstein (1984). 'Employee ownership, work attitudes, and power relationships’. Academy of Management Journal, 27, pp. 861-869.

Guedri, Z. and Hollandts, X. (2008). 'Beyond Dichotomy: The Curvilinear Impact of Employee Ownership on Firm Performance'. Corporate Governance, 16: 460-474.

Hammer, T., R. Stern and R. Gurdon, R (1982). 'Worker ownership and attitudes toward participation’. In: F. Lindenfeld and J. Rothschild-Whitt (eds.), Workplace Democracy and Social Change. Boston, MA: Porter Sargent Publishers.

HM Revenue and Customs. (2012). Companies with Tax-Advantaged Employee Share Schemes. Available at: http://www.hmrc.gov.uk/stats/emp_share_schemes/companies.pdf. Hornby, P. and G. Symon (1994). Tracer studies. In: C. Cassell and G. Symon (eds), Qualitative Methods in Organizational Research: A Practical Guide. Sage, London.

Hsu, D. K., Shinnar, R. S., \& Powell, B. C. (2014). Expectancy theory and entrepreneurial motivation: A longitudinal examination of the role of entrepreneurship education. Journal of Business and Entrepreneurship, 26(1), 121-140.

Illes, J. (Ed.). (2006). Neuroethics: Defining the issues in theory, practice, and policy. Oxford University Press.

Jackson, C. and G. Morgan (2011). Employee participation in UK Sharesave schemes: a 
firm-level analysis. The International Journal of Human Resource Management, 22, pp. $1788-1802$.

Jones, D. and T. Kato (1995). 'The productivity effects of employee stock-ownership plans and bonuses: evidence from Japanese panel data'. The American Economic Review, 85, pp. 391-414.

Kaarsemaker, E., Pendleton, A. and Poutsma, E. (2009). ‘Employee share ownership plans: A review’. University of York, York, UK. Available at: http://eprints.whiterose.ac.uk/8883/.

Kaarsemaker, E., Pendleton, A. and Poutsma, E. (2010). ‘Employee share ownership plans: A review’. In: A. Wilkinson., M. Marchington, P. Gollan and D. Lewin (eds) Oxford Handbook of Participation in Organisations. Oxford: Oxford University Press, pp. 315-317.

Keef, S. P. (1998). The causal association between employee share ownership and attitudes: A study based on the Long framework. British Journal of Industrial Relations, 36, 73-82.

Kelly, J. E. and C. W. Clegg (Eds.). (1982). Autonomy and control at the workplace: context for job redesign. London: Routledge.

Klein, K. (1987). 'Employee stock ownership and employee attitudes: a test of three models'. Journal of Applied Psychology, 72, pp. 319-32.

Klein, K.J. and Hall, R.J. (1988), ‘Correlates of Employee Satisfaction with Stock Ownership: Who Likes an ESOP Most?’ Journal of Applied Psychology, 73, 630-638.

Knyght, P., A. Kouzmin, N. Kakabadse and A. Kakabadse (2010). 'Auditing employee ownership in a neo-liberal world’. Management Decision, 48, pp. 1304-1323.

Kruse, D. (1984) Employee Ownership and Employee Attitudes: Two Case Studies. Norwood, PA: Norwood Editions.

Kruse, D. L. (1996). Why do firms adopt profit-sharing and employee ownership plans? British Journal of Industrial Relations, 34, 515-538.

Kruse, D. (2002). 'Research evidence on prevalence and effects of employee ownership’. The 
National Centre for Employee Ownership. Presented in testimony before the Subcommittee on Employer-Employee Relations, U.S. House of Representatives. Available at: http://ownershipassociates.com/kruse.shtm.

Kuvaas, B. (2006). 'Work performance, affective commitment, and work motivation: the roles of pay administration and pay level’. Journal of Organizational Behavior, 27, pp. 365-385.

Landau, I., R. Mitchell, A. O’Connell and I. Ramsey (2007). 'Employee share ownership: a review of the literature'. Employee Share Ownership Project, Melbourne Law School, The University of Melbourne, Australia. Available at:

http://cclsr.law.unimelb.edu.au/files/Employee_Share_Ownership_a_Review_of_the_Literat ure1.pdf.

Long, R. (1978a). 'The relative effects of share ownership vs. control on job attitudes in an employee-owned company’. Human Relations, 31, pp. 753-63.

Long, R. (1978b). 'The Effects of Employee Ownership on Organizational Identification, Employee Job attitudes, and organizational performance: A tentative framework and empirical findings’. Human Relations, 31, pp. 29-48.

Long, R. (1982). 'Worker ownership and job attitudes: a field study’. Industrial Relations, 21, pp. 196-215.

Maaløe, E. (1998). The employee owner: organizational and individual change within manufacturing companies as participation and sharing grow and expand. Copenhagen: Academic Press.

Markowitz, H. M., Blasi, J. R. and D. L. Kruse (2010). Employee stock ownership and diversification. Annals of Operations Research, 176, pp. 95-107.

Mayhew, M., N. Ashkanasy, T. Bramble and J. Gardner (2007). 'A study of the antecedents and consequences of psychological ownership in organizational settings'. The Journal of Social Psychology, 147, pp. 477- 500. 
McCarthy, D., \& Palcic, D. (2012). The impact of large-scale employee share ownership schemes on labor productivity: The case of Eircom. The International Journal of Human Resource Management, 23, 3710-3724.

McCarthy, D., E. Reeves and T. Turner (2010). 'Can employee share-ownership improve employee attitudes and behaviour?’. Employee Relations, 32, pp. 382-395.

Meyer, J. and N. Allen (1984). 'Testing the 'side bet theory' of organizational commitment: Some methodological considerations’. Journal of Applied Psychology, 69, pp. 372-378.

Meyer, J. and N. Allen (2002). 'Affective, continuance, and normative commitment to the organization: A meta-analysis of antecedents, correlates, and consequences'. Journal of Vocational Behavior, 61, pp. 20-52.

Minbaeva, D. (2008). 'HRM practices affecting extrinsic and intrinsic motivation of knowledge receivers and their effect on intra-MNC knowledge transfer'. International Business Review, 17, pp. 703-713.

Nisbett, R. and T. Wilson (1977). 'Telling More than we can know: verbal reports on mental processes’, Psychological Review, 84, pp. 231-259.

Pendleton, A. (2001) Employee Ownership, Participation and Governance. A study of ESOPs in the UK. London: Routledge.

Pendleton, A. (2010). 'Employee participation in employee share ownership: an evaluation of the factors associated with participation and contributions in Save as You Earn Plans'. British Journal of Management, 21, pp. 555-570.

Pendleton, A. and A. Robinson (2010). ‘Employee stock ownership, involvement, and productivity: an interaction-based approach’. Industrial and Labor Relations Review, 64, pp. 3-29.

Pendleton, A., N. Wilson and M. Wright (1998). 'The perception and effects of share 
ownership: empirical evidence from employee buy-outs’. British Journal of Industrial Relations, 36, pp. 99-124.

Pierce, J., S. Rubenfeld and S. Morgan (1991). 'Employee ownership: a conceptual model of process and effects'. Academy of Management Review, 16, pp. 121-144.

Porter, L., R. Steers, R. Mowday and R. Boulian (1974). ‘Organizational commitment, job satisfaction, and turnover among psychiatric technicians’, Journal of Applied Psychology, 59, pp. 603-609.

Poutsma, E., P. Kalmi and A. Pendleton (2006), ‘The relationship between financial participation and other forms of employee participation: new survey evidence from Europe'. Economic and Industrial Democracy, 27, pp. 637-68.

Richter, A. and Schrader, S. (2016), Levels of employee share ownership and the performance of listed companies in Europe. British Journal of Industrial Relations. [Online]

Robinson, A. M., and Wilson, N. (2006). Employee financial participation and productivity: An empirical reappraisal. British Journal of Industrial Relations,44, 31-50.

Rousseau, D., Shperling, Z. (2003), 'Pieces of the Action: Ownership and the Changing Employment Relationship', Academy of Management Review, 28, 533-570.

Sengupta, S., A. Pendleton and K. Whitfield (2010). 'How employee share ownership structure shapes the ESO/performance relationship: An analysis using WERS 2004'. The British Academy of Management Conference, University of Sheffield, UK.

Sengupta, S., K. Whitfield and R. McNabb (2007). 'Employee share ownership and performance: golden path or golden handcuffs?' International Journal of Human Resource Management, 18, pp. 1507-538.

Sesil. J., M. Kroumova, J. Blasi and D. Kruse (2002). 'Broad- based employee stock options in US ‘new economy’ firms’. British Journal of Industrial Relations, 40, pp. 273-294. 
Tucker, J., S. Nock and D. Toscano (1989). 'Employee ownership and perceptions of work: the effect of an employee stock ownership plan’. Work and Occupations, 16, pp. 26-46.

VandeWalle, D., L. Van Dyne and T. Kostova (1995). 'Psychological ownership: an empirical examination of its consequences’. Group and Organization Management, 20, pp. $210-226$.

Vroom, V. (1964). Work and Motivation. New York: Wiley.

Walther, H. (2010). Anomalies in intertemporal choice, time-dependent uncertainty and expected utility-A common approach. Journal of Economic Psychology, 31, pp. 114-130.

\footnotetext{
${ }^{1}$ Of the four HMRC approved (tax-advantaged) share plans in the UK, the sponsors of this study expressed their interest in understanding more about the impact of the SAYE, SIP and EMI plans on employee attitudes and behaviours at work. The SAYE and SIP (at the time of data collection) were the two most frequently used, government approved, all employee share schemes in the UK. Of the discretionary schemes, the EMI scheme was more frequently adopted by companies than the CSOP and was chosen to contrast the SIP and SAYE - both of which are all employee plans that can be operated in large companies.
} 
Table 1: Sample criteria and characteristics of the chosen companies and employees

\begin{tabular}{|c|c|c|c|c|c|c|c|c|c|}
\hline & Company 1 & Company 2 & Company 3 & Company 4 & Company 5 & Company 6 & Company 7 & Company 8 & Company 9 \\
\hline \multicolumn{10}{|l|}{ Company Details } \\
\hline ESO scheme & SIP & SIP & SIP & EMI & EMI & EMI & SAYE & SAYE & SAYE \\
\hline $\begin{array}{l}\text { Year ESO } \\
\text { Scheme } \\
\text { Introduced }\end{array}$ & 2008 & 2007 & 2003 & 2008 & 2004 & 2007 & 1985 & 1981 & 1985 \\
\hline Industry & Real Estate & $\begin{array}{c}\text { Market } \\
\text { Research }\end{array}$ & $\begin{array}{l}\text { Biology/ } \\
\text { Consumer } \\
\text { Care }\end{array}$ & Care Service & $\begin{array}{l}\text { Neuro- } \\
\text { scientific } \\
\text { Research }\end{array}$ & $\begin{array}{l}\text { Management } \\
\text { Consultancy }\end{array}$ & Tele-comms & Retail & $\begin{array}{l}\text { Financial } \\
\text { Services }\end{array}$ \\
\hline $\begin{array}{l}\text { Number of } \\
\text { Employees }\end{array}$ & 42 & 850 & 3500 & 850 & 22 & 11 & 105,000 & 75,000 & 204,200 \\
\hline $\begin{array}{l}\text { ESO scheme(s) } \\
\text { in place }\end{array}$ & SIP & SIP & SIP \& SAYE & $\begin{array}{l}\text { EMI \& } \\
\text { SAYE }\end{array}$ & EMI & EMI & SIP \& SAYE & SAYE & SIP \& SAYE \\
\hline $\begin{array}{l}\text { Age of Business } \\
\text { (yrs) }\end{array}$ & $10-15$ & $15-20$ & $15-20$ & $1-5$ & $5-10$ & $1-5$ & $20+$ & $20+$ & $20+$ \\
\hline \multicolumn{10}{|c|}{ Employees Interviewed } \\
\hline Male & 2 & 2 & 2 & 3 & 2 & 3 & 4 & 1 & 2 \\
\hline Female & 2 & 2 & 3 & 1 & 2 & 1 & 0 & 3 & 3 \\
\hline \multicolumn{10}{|l|}{ Year of Interview } \\
\hline 2009 & 0 & 4 & 0 & 4 & 4 & 4 & 4 & 0 & 5 \\
\hline 2010 & 4 & 0 & 4 & 0 & 0 & 0 & 0 & 4 & 0 \\
\hline \multicolumn{10}{|c|}{ Length of Employment (yrs) } \\
\hline Up to 3 & 1 & 1 & 1 & 0 & 3 & 3 & 1 & 0 & 0 \\
\hline $\begin{array}{l}\text { More than } 3 \text { and } \\
\text { up to } 10\end{array}$ & 3 & 2 & 2 & 2 & 1 & 1 & 1 & 0 & 1 \\
\hline More than 10 & 0 & 1 & 1 & 2 & 0 & 0 & 2 & 4 & 4 \\
\hline
\end{tabular}




\section{Table 1 (Continued):}

\begin{tabular}{|c|c|c|c|c|c|c|c|c|c|}
\hline \multicolumn{10}{|c|}{ Length of time participating in ESO Scheme (yrs) } \\
\hline 1 year or less & 0 & 0 & 0 & 4 & 1 & 1 & 0 & 0 & 0 \\
\hline $\begin{array}{l}\text { More than } 1 \\
\text { year and up to } 3 \\
\text { years }\end{array}$ & 4 & 4 & 2 & 0 & 2 & 3 & 1 & 0 & 0 \\
\hline $\begin{array}{l}\text { More than } 3 \\
\text { years and up to } \\
5 \text { years }\end{array}$ & 0 & 0 & 1 & 0 & 1 & 0 & 0 & 0 & 0 \\
\hline $\begin{array}{l}\text { More than } 5 \\
\text { years and up to } \\
10 \text { years }\end{array}$ & 0 & 0 & 1 & 0 & 0 & 0 & 2 & 0 & 3 \\
\hline $\begin{array}{l}\text { More than } 10 \\
\text { years and up to } \\
20 \text { years }\end{array}$ & 0 & 0 & 0 & 0 & 0 & 0 & 0 & 2 & 2 \\
\hline $\begin{array}{l}\text { More than } 20 \\
\text { years }\end{array}$ & 0 & 0 & 0 & 0 & 0 & 0 & 1 & 2 & 0 \\
\hline \multicolumn{10}{|c|}{ Gross Earnings $(£)$} \\
\hline Up to 24,999 & 1 & 0 & 3 & 0 & 1 & 0 & 0 & 2 & 0 \\
\hline $25,000-54,999$ & 3 & 2 & 1 & 2 & 2 & 2 & 1 & 2 & 3 \\
\hline $55,000+$ & 0 & 2 & 0 & 2 & 1 & 2 & 3 & 0 & 2 \\
\hline $\begin{array}{l}\text { Financial } \\
\text { Investment of } \\
\text { each person }^{1}\end{array}$ & $\begin{array}{c}1,133 \\
\text { Unknown } \\
\text { Unknown } \\
1500\end{array}$ & $\begin{array}{c}4880 \\
\text { Unknown } \\
2000 \\
3000 \\
\end{array}$ & $\begin{array}{c}\text { Unknown } \\
10,000 \\
2,303 \\
1,500 \\
\end{array}$ & $\begin{array}{c}<30,000 \\
30,000- \\
50,000 \text { x2 } \\
\text { Unknown }\end{array}$ & $\begin{array}{c}<30,000 \times 2 \\
\text { Unknown x2 }\end{array}$ & $\begin{array}{c}<30,000 \\
\text { Unknown x3 }\end{array}$ & $\begin{array}{c}225 \times 3 \\
108\end{array}$ & $\begin{array}{c}15 \\
250 \\
30 \\
150 \\
\end{array}$ & $\begin{array}{c}250 \times 3 \\
200 \\
100\end{array}$ \\
\hline
\end{tabular}

${ }^{1}$ For SIP and EMI this is value of shares or options held. For SAYE it is amount saved per month. Unknown means the interviewee didn't know. 


\section{Appendix 1}

SIP, EMI and SAYE Schemes

\begin{tabular}{|l|l|}
\hline SIP & $\begin{array}{l}\text { SIP participants become shareholders as soon as they participate. The SIP has three key } \\
\text { elements: employers can give employees up to } £ 3,000 \text { worth of free shares each year; } \\
\text { employees can buy up to } £ 1,500 \text { of 'partnership shares'; and employers can give } \\
\text { participants up to two free shares for every partnership share bought (matching shares). } \\
\text { Performance conditions can also be attached to the award of SIP shares. }\end{array}$ \\
\hline EMI & $\begin{array}{l}\text { EMI share options are intended to help smaller, higher risk companies. Employees can } \\
\text { be selected and granted options (at a fixed exercise price) over shares worth up to } \\
£ 120,000 \text { at date of grant. Once granted EMI options, participants are required to wait } \\
\text { until three years after the last of these options was granted before any more options can } \\
\text { be granted. Options can be granted at any exercise price. }\end{array}$ \\
\hline SAYE & $\begin{array}{l}\text { In SAYE, employees can be given the right (option) to buy shares in the company and } \\
\text { sell (exercise) the shares at a price, which is fixed when the option is granted. Between } \\
£ 5 \text { and £250 per month can be saved in an SAYE savings contract. This can last for } \\
\text { three, five or seven years. The savings made during this period can be used to buy the } \\
\text { shares if the employee chooses to exercise their options. Alternatively, participants can } \\
\text { receive the proceeds of the SAYE contract (savings). }\end{array}$ \\
\hline
\end{tabular}




\section{Appendix 2}

Additional contextual information about each participating company

\begin{tabular}{|c|c|}
\hline $\begin{array}{l}\text { Company } 1 \\
\text { SIP } \\
\text { Real Estate }\end{array}$ & $\begin{array}{l}\text { Uses free share offers only, not partnership or matching share offers. Number of shares } \\
\text { depends on company performance, tenure, status and hours worked. Tax advantages to } \\
\text { keeping the shares for three years. Shares surrendered on dismissal or voluntary } \\
\text { turnover. Scheme introduced partly to protect company mission. ESO manager expects } \\
\text { a modest incremental effect on tenure, motivation and "feeling part" of the company } \\
\text { but worries that shareholdings may be too small to achieve that. }\end{array}$ \\
\hline $\begin{array}{l}\text { Company } 2 \\
\text { SIP } \\
\text { Market } \\
\text { Research }\end{array}$ & $\begin{array}{l}\text { Uses partnership and matching shares, not free shares. For every } 17 \text { shares an employee } \\
\text { buys, the company gives three. These are not subject to performance conditions. There } \\
\text { are tax incentives to keep the shares for five years. Voluntary leavers can sell their } \\
\text { shares (though subject to taxes). ESO manager said the scheme was introduced because } \\
\text { it would be well-received and encourage people to be "emotionally and financially tied } \\
\text { to the company." }\end{array}$ \\
\hline $\begin{array}{l}\text { Company } 3 \\
\text { SIP } \\
\text { Biology/ } \\
\text { Consumer } \\
\text { Care }\end{array}$ & $\begin{array}{l}\text { Uses partnership and matching shares, not free shares. After one year in the company } \\
\text { employees can use up to } £ 125 \text { per month to buy shares at the market rate, which are } \\
\text { then matched by free shares from the company. No performance conditions. Sale of } \\
\text { shares before three years means loss of matching shares and tax liability. Between } 3 \\
\text { and } 5 \text { years, tax only, no loss of matching shares. ESO manager said "staff retention, } \\
\text { that's the main point”, via financial incentives and reinforcing family business ethos. }\end{array}$ \\
\hline $\begin{array}{l}\text { Company } 4 \\
\text { EMI } \\
\text { Care Service }\end{array}$ & $\begin{array}{l}\text { EMI scheme is limited to those defined by senior management as key employees; about } \\
11 \% \text { of the total at the time of data collection. There was no formal definition of a key } \\
\text { employee. ESO manager indicated that those offered shares would interpret it as } \\
\text { signalling their value to the company. Shares are allocated after about three years. They } \\
\text { do not give voting rights. }\end{array}$ \\
\hline $\begin{array}{l}\text { Company } 5 \\
\text { EMI } \\
\text { Neuro- } \\
\text { scientific } \\
\text { Research }\end{array}$ & $\begin{array}{l}\text { Employees joining the scheme are, over } 3 \text { years, allocated the same number of share } \\
\text { options as their salary in UK pounds. However, whether they receive all of these } \\
\text { depends on their performance. Employees have three years to exercise the shares. } \\
\text { Voluntarily leaving the company leads to loss of the options they have been granted. } \\
\text { ESO manager thought ESO was to "lead employees to feel some form of ownership", } \\
\text { which produced financial gain through individual and company performance. }\end{array}$ \\
\hline $\begin{array}{l}\text { Company } 6 \\
\text { EMI } \\
\text { Management } \\
\text { Consultancy }\end{array}$ & $\begin{array}{l}\text { Options are typically granted once a year for non-voting equity, equating to } 2 \% \text { of the } \\
\text { business. The amount received by each participating employee depends on their salary } \\
\text { and bonus. Options can be exercised ten years after the grant, or when the company is } \\
\text { sold. The company founders wanted to spread wealth, not dilute control. }\end{array}$ \\
\hline $\begin{array}{l}\text { Company } 7 \\
\text { SAYE } \\
\text { Telecoms }\end{array}$ & $\begin{array}{l}\text { The scheme has been running for more than } 25 \text { years. Employees can participate in } \\
\text { three year or five year contracts. About } 55 \% \text { of the workforce participates. Options do } \\
\text { not give voting rights. The employee has to exercise the options and become a } \\
\text { shareholder for that. ESO manager thought that scheme was seen as a key benefit that } \\
\text { affected satisfaction, motivation, knowledge of the stock market and enabled } \\
\text { employees to accumulate extra wealth. }\end{array}$ \\
\hline $\begin{array}{l}\text { Company } 8 \\
\text { SAYE } \\
\text { Retail }\end{array}$ & $\begin{array}{l}\text { Has previously used SIP. Three year contracts are offered to employees. Voting rights } \\
\text { work as in company } 7 \text {. ESO manager said the scheme was to encourage employees to } \\
\text { "feel part of the business", and was also an aspect of corporate social responsibility, } \\
\text { enabling employees to plan for a financially secure future. }\end{array}$ \\
\hline
\end{tabular}




\begin{tabular}{|l|l|}
\hline Company 9 & The scheme has been running for more than 25 years. Employees are offered 3, 5 or 7 \\
SAYE & year contracts. Voting rights as in companies 7 and 8. About $79 \%$ of the workforce \\
Financial & $\begin{array}{l}\text { participates. ESO manager said the scheme was introduced primarily to enable } \\
\text { employees to make extra money, but a crash in the share price had made this an } \\
\text { Services }\end{array}$ \\
\hline
\end{tabular}

Endnote 